\title{
A PRELIMINARY STUDY OF CARBON DEPOSITION ON ZINC FERRITE SORBENTS \\ Toplcal Report for Task 9
}

By

G. N. Krishnan

V. K. Wong

B. J. Wood

August 1991

Work Performed Under Contract No. AC21-88MC25006

For

U.S. Department of Energy

Morgantown Energy Technology Center

Morgantown, West Virginla

By

Research Triangle Institute

Research Trlangle Park, North Carolina

and

SRI Intemational

Menio Park, Callfornia 


\section{DISCLAIMER}

This report was prepared as an account of work sponsored by an agency of the United States Government. Neither the United States Government nor any agency thereof, nor any of their employees, makes any warranty, express or implied, or assumes any legal liability or responsibility for the accuracy, completeness, or usefulness of any information, apparatus, product, or process disclosed, or represents that its use would not infringe privately owned rights. Reference herein to any specific commercial product, process, or service by trade name, trademark, manufacturer, or otherwise does not necessarily constitute or imply its endorsement, recommendation, or favoring by the United States Government or any agency thereof. The views and opinions of authors expressed herein do not necessarily state or reflect those of the United States Government or any agency thereof.

This report has been reproduced directly from the best available copy.

Available to DOE and DOE contractors from the Office of Scientific and Technical Information, P.O. Box 62, Oak Ridge, TN 37831; prices available from (615)576-8401, FTS 626-8401.

Available to the public from the National Technical Information Service, U.S. Department of Commerce, 5285 Port Royal Rd., Springfield, VA 22161. 


\title{
A Preliminary Study of Carbon Deposition on Zinc Ferrite Sorbents
}

Topical Report for Task 9

\author{
G.N. Krishnan \\ V.K. Wong \\ B.J. Wood
}

Work Performed Under Contract No.: DE-AC21-88MC25006

For

U.S. Department of Energy

Office of Fossil Energy

Morgantown Energy Technology Center

P.0. Box 880

Morgantown, West Virginia 26507-0880

\author{
By \\ Research Triangle Institute \\ P.O. Box 12194 \\ Research Triangle Park, North Carolina 27709 \\ and \\ SRI International \\ 333 Ravenswood Avenue \\ Menlo Park, California 94025-3493
}

August 1991 


\begin{abstract}
A preliminary study was conducted to determine the feasibility of cumulative carbon deposition on zinc ferrite sorbents under conditions relevant to desulfurization of hot coal gas from the KRW fluidized bed gasifier operating in the air-blown mode. Thermodynamic calculations indicated that the range of conditions under which carbon deposition and carbide formation occur can be broadened if the gas contains less than equilibrium levsls of methane. These calculations also indicated that dissociation of $\mathrm{CO}$ and reduction of $\mathrm{CO}$ by hydrogen are potential pathways for carbon deposition on the sorbent.

A laboratory fixed-bed reactor was used to deposit carbon on fresh and sulfided zinc ferrite specimens at $550^{\circ} \mathrm{C}$ and 15 atm using $\mathrm{CO} / \mathrm{CO}_{2}, \mathrm{C}_{2} \mathrm{H}_{4}$, or $\mathrm{C}_{6} \mathrm{H}_{6}$ as feedstocks in a helium or nitrogen carrier gas. The reactivity and quantity of deposited carbon were determined by the temperature programmed reaction technique in which the sorbent was heated at a rate of $8^{\circ} \mathrm{C} / \mathrm{min}$ in a flowing steam-helium mixture at $15 \mathrm{~atm}$ while the evolution of $\mathrm{CO}, \mathrm{CO}_{2}$, and $\mathrm{CH}_{4}$ was measured as a function of sorbent temperature. $\mathrm{CO}_{2}$ and $\mathrm{CO}$ were the major and minor products of the gasification of deposited carbon. The level of $\mathrm{CH}_{4}$ produced during the reaction with steam was negligibly small.

The results of the experiments indicated that carbon deposited from a $\mathrm{CO} / \mathrm{CO}_{2}$ mixture and hydrocarbons such as $\mathrm{C}_{2} \mathrm{H}_{4}$ and $\mathrm{C}_{6} \mathrm{H}_{6}$ may continuously accumulate on zinc ferrite sorbent because the rate of carbon removal by steam was slow. Additional research studies are needed to determine (1) thermodynamics and kinetics of carbon deposition and carbide formation on zinc ferrite and other hot coal gas desulfurization sorbents and (2) the change in the atrition resistance of the sorbents induced by carbon deposition and carbide formation.
\end{abstract}




\section{CONTENTS}

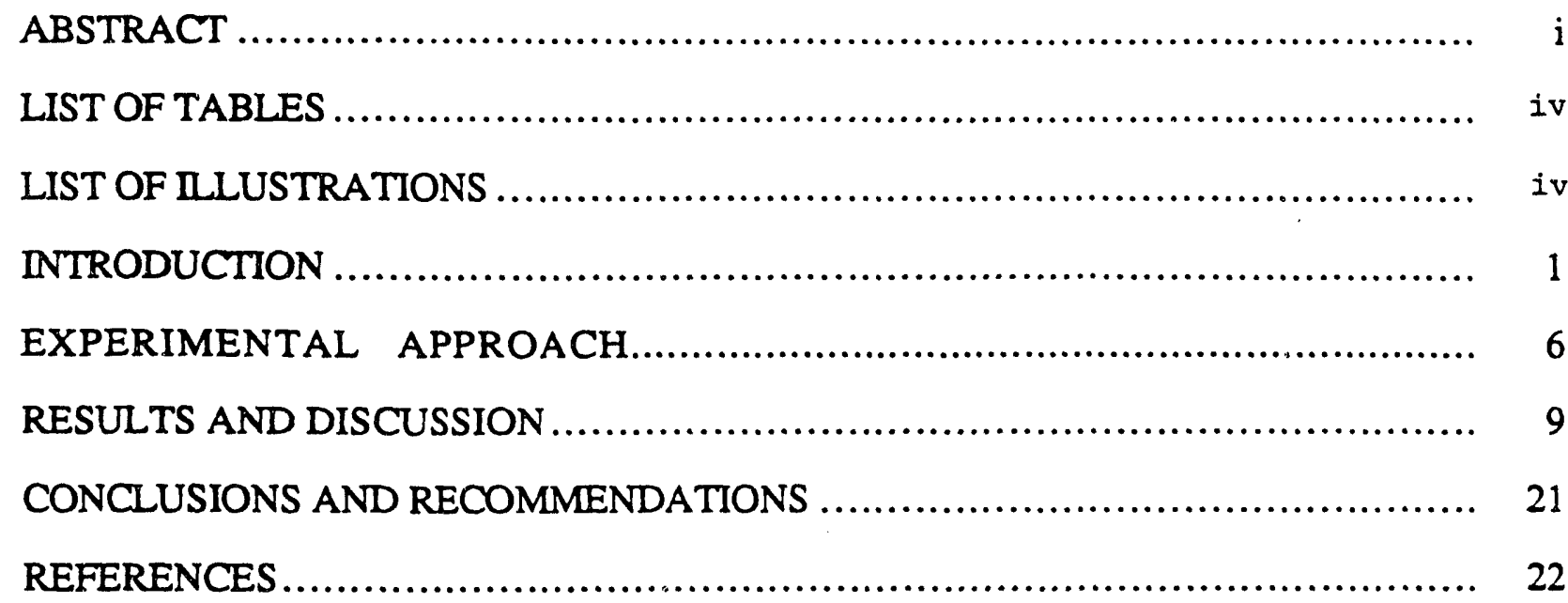




\section{TABLES}

1. Actual and equilibrium compositions of the prodcut gas stream of the KRW fluidized bed Gasifier

2. Quantity of carbon deposit removed by steam gasification ......................... 17

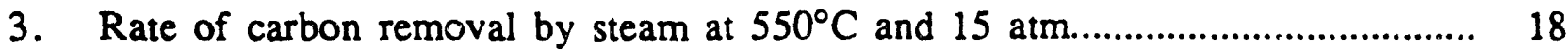

\section{ILLUSTRATIONS}

1. Activity of carbon as a function of temperature .................................... 2

2. Carbon and carbide boundary lines in a $\mathrm{C}-\mathrm{H}-\mathrm{O}$ system at $550^{\circ} \mathrm{C}$ and $15 \mathrm{arm} \ldots \ldots \ldots . .5$

3. Schematic diagram of the reactor system ............................................ 7

4. TPR spectrum of carbon present in the zinc ferrite (as received) ...................... 10

5. TPR spectrum of carbon deposited by a high $\mathrm{CO} / \mathrm{CO}_{2}$ gas mixture on a zinc ferrite sorbent ..................................................................... 11

6. TPR spectrum of carbon deposited by a low $\mathrm{CO} / \mathrm{CO}_{2}$ gas mixture on a zinc ferrite sorbent ......................................................................... 12

7. TPR spectrum of carbon deposited by ethyiene on a zinc ferrite sorbent ............... 13

8. TPR spectrum of carbon deposited by benzene on a zinc ferrite sorbent ............... 14

9. TPR spectrum of carbon deposited by a low $\mathrm{CO} / \mathrm{CO}_{2}$ mixture on a sulfided5 zinc ferrite sorbent................................................................. 15

10. TPR spectrum of carbon deposited by a low ethylene gas mixture on a sulfided zinc ferrite sorbent.................................................................... 16

11. Plot of $\log$ (rate of carbon removal/amount of carbon remaining)vs inverse temperature 20 


\section{INTRODUCTION}

Regenerable zinc ferrite sorbents have been shown to reduce the level of sulfur species to less than $10 \mathrm{ppm}$ in hot coal gas streams at temperatures in the range $500^{\circ}$ to $650^{\circ} \mathrm{C}$. Carbon deposition and carbide formation have a deleterious effect on the mechanical integrity of the sorbents, and they must be avoided. In pilot plant runs, carbon deposition and carbide formation on zinc ferrite sorbents were observed under conditions in which global thermodynamic equilibrium calculations predict that such reactions should not occur. Adding steam to the hot coal gas to prevent carbon deposition is undesirable because it reduces the heating value of the gas and affects the efficiency of power generation in gas turbines.

Global thermodynamic equilibrium calculations such as Gibbs energy minimization programs assume that all possible reactions will occur and that the system will be at its lowest Gibbs energy state. However, such thermodynamic equilibrium may not be attainable in practice because reactions among some species may be slow while others are rapid. Fast reactions might include those that deposit carbon, such as rapid pyrolysis of hydrocarbons or disproportionation of $\mathrm{CO}$, while removal of carbon deposits by reaction with $\mathrm{CO}_{2}$ or $\mathrm{H}_{2} \mathrm{O}$ may be slow. Thus the net rate of carbon deposition may depend on the respective kinetics of the deposition and gasification reactions. An unfavorable balance in these rates would lead to an accumulation of carbon on the sorbents, despite the predictions of global equilibrium calculations.

The source of carbon in a hot coal gas may be $\mathrm{CO}, \mathrm{CH}_{4}$ or other hydrocarbons. Figure 1 illustrate the activity of carbon in equilibrium with a hot coal gas mixture representative of an airblown KRW fluidized bed gasifier. In this diagram thermodynamic data for individual reactions were used to calculate the thermodynamic activity of carbon in the gas phase. The thermodynamic activity of carbon in the gas, relative to graphite, must be greater than unity for carbon deposition to occur (Turkdogan, 1980). The calculations indicate that the disproportionation of $\mathrm{CO}$ and the reaction of $\mathrm{CO}$ with $\mathrm{H}_{2}$ yield carbon activities greater than unity. The carbon deposit can be removed by reaction with $\mathrm{H}_{2}$ in the coal gas, and this reaction is thermodynamically favorable under $\mathrm{KRW}$ gasifier stream conditions. When methane is included as a reactive species in the carbon formation and removal reactions, then the thermodynamic equilibrium calculations indicate that carbon deposition should not occur. This conclusion is in agreement with the calculations 


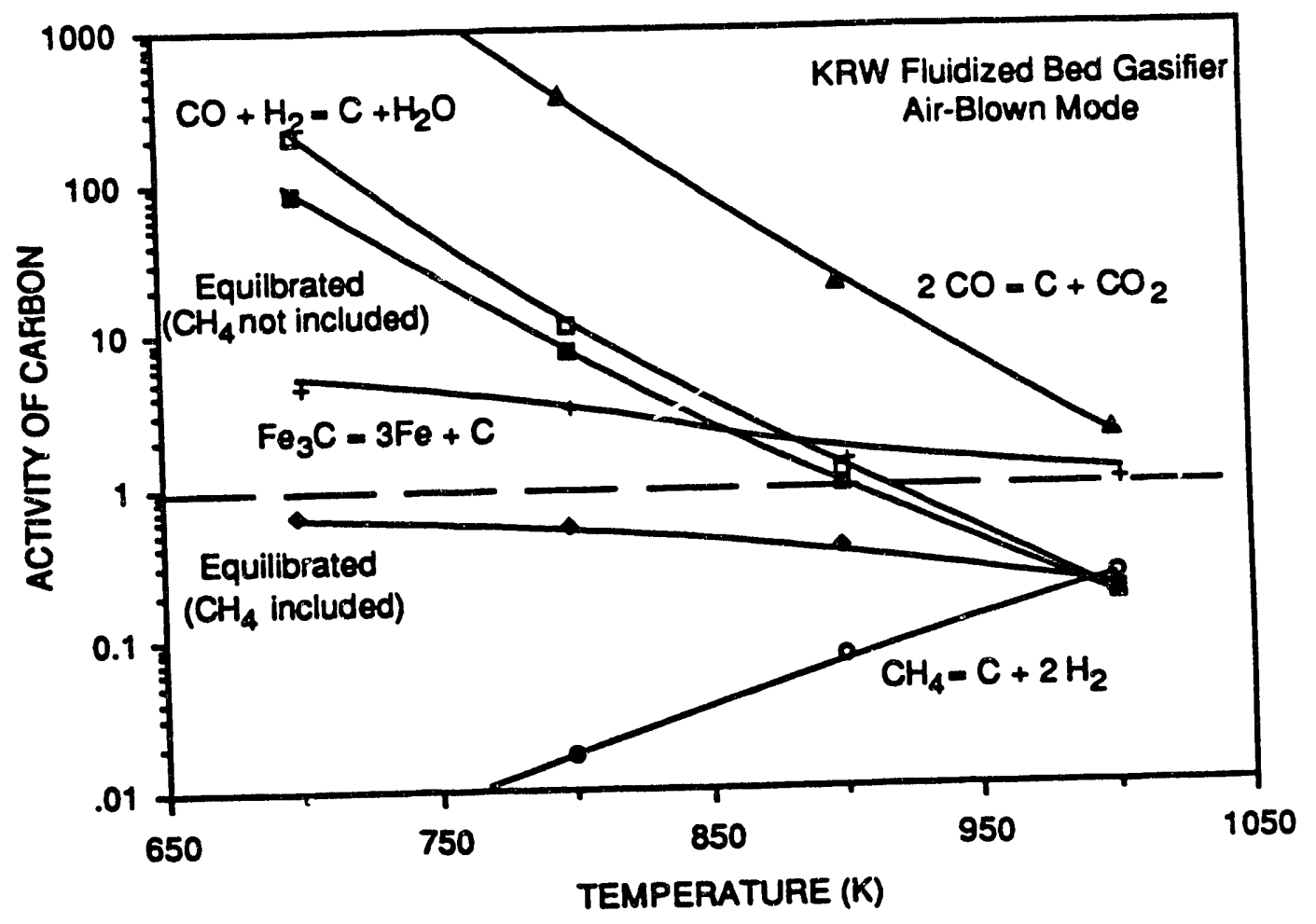

CAM-1954-1

Figure 1. Activity of carbon as a function of temperature. 
performed by Lamoreaux et al. (1986). However, if methane is not included in the calculations, then carbon deposition can oczur below a temperature of about $900 \mathrm{~K}$.

The concentration of methane in the hot coal gas streams can be significantly less than indicated by equilibrium calculations. Indeed, thermodynamic calculations using a Gibbs energy minimization program (Reynolds, 1986) indicate that the partial pressure of $\mathrm{CH}_{4}$ in the KRW gasifier product gas stream should be about $0.50 \mathrm{~atm}$ at $823 \mathrm{~K}$ but the reported measured partial pressure is only $0.036 \mathrm{~atm}$ (Table 1 ). Comparison of the reported composition and equilibrium values indicates that the measured partial pressure of $\mathrm{CO}$ is an order-of-magnitude higher than the equilibrium value which can lead to carbon deposition by disproportionation ( $\left.2 \mathrm{CO}=\mathrm{C}+\mathrm{CO}_{2}\right)$. The measured partial pressure of $\mathrm{CO}_{2}$ is lower than the equilibrium value because of reactions such as $2 \mathrm{CO}+2 \mathrm{H}_{2}=\mathrm{CH}_{4}+\mathrm{CO}_{2}$ are not reaching equilibrium.

Formation of $\mathrm{CH}_{4}$ either by gasification of carbon or by reaction of $\mathrm{CO}$ with $\mathrm{H}_{2}$ is an activated process, and significant rates are achievable only in the presence of a suitable catalyst. Whereas metals such as $\mathrm{Fe}$ and $\mathrm{Ni}$ are excellent catalysts for the methane formation reactions, the transition metal oxides do not exhibit high activities. Slow rates of methane formation can broaden the range of conditions under which carbon deposition may occur on zinc ferrite sorbents.

Thermodynamic calculations were performed for defining boundary conditions for carbon (graphite) and carbide [cementite $\left(\mathrm{Fe}_{3} \mathrm{C}\right)$ ] formation at $823 \mathrm{~K}$ and $15 \mathrm{~atm}$ total pressure. $\mathrm{Fe}_{3} \mathrm{C}$ was assumed to be formed by either reduction of $\mathrm{Fe}_{3} \mathrm{O}_{4}$ or reaction of $\mathrm{C}$ with $\mathrm{Fe}$. Calculations were performed both including and excluding $\mathrm{CH}_{4}$ as a reactive component. For the $\mathrm{C}(\mathrm{s})$ or $\mathrm{Fe}_{3} \mathrm{C}(\mathrm{s}) / \mathrm{Fe}(\mathrm{s})$ boundaries, the thermodynamic activity of carbon was defined and the triagonal curves (Figure 2, lines 2 and 4, and $\mathrm{H}$-rich portions of lines 1 and 3) were determined by setting the partial pressure of $\mathrm{H}_{2}$ between 0 and $15 \mathrm{~atm}$ and calculating the oxygen chemical potential for a total pressure of $15 \mathrm{~atm}$. For the $\mathrm{Fe}_{3} \mathrm{O}_{4}(\mathrm{~s}) / \mathrm{Fe} 3 \mathrm{C}(\mathrm{s})$ boundary, the $\mathrm{H}_{2}$ partial pressure was set and the thermodynamic activity of iron ( $\mathrm{Fe} \leq 1$ ) was calculated from the total pressure constraint. The results of the calculations, shown in Figure 2, indicate that carbon deposition would not occur in $\mathrm{KRW}$ coal gas at $550^{\circ} \mathrm{C}$ when the gas mixture is equilibrated by methanation and water gas shift reactions. Without methane formation, the equilibrated KRW coal gas is located near the $\mathrm{Fe}_{3} \mathrm{C} / \mathrm{Fe}_{3} \mathrm{O}_{4}$ boundary and well within the $\mathrm{C}(\mathrm{s})$ deposition boundary. Under such conditions, the gas is rich in $\mathrm{CO}$ and is capable of deposition of solid carbon. 
Table 1

ACTUAL AND EQUILIBRIUM COMPOSITIONS OF THE PRODUCT GAS STREAM OF JiU KRW FLUIDIZED BED GASIFIER

\begin{tabular}{|c|c|c|}
\hline cosumenent & Beported Compesition ${ }^{1}$ & Equllibrlum Compesition \\
\hline 60 & 10.55 & 0.91 \\
\hline $\mathrm{CO}_{\mathrm{c}}$ & 4.64 & 12.15 \\
\hline $\mathrm{CH}_{4}$ & 0.24 & 3.32 \\
\hline $\mathrm{H}_{2}$ & 8.26 & 6.80 \\
\hline$v_{2}$ & 48.73 & 51.72 \\
\hline $\mathrm{HaS}$ & 0.06 & 0.06 \\
\hline $\mathrm{H}_{2} \mathrm{O}$ & 27.52 & 25.04 \\
\hline
\end{tabular}

1 From Haldipur et al. (1989). 


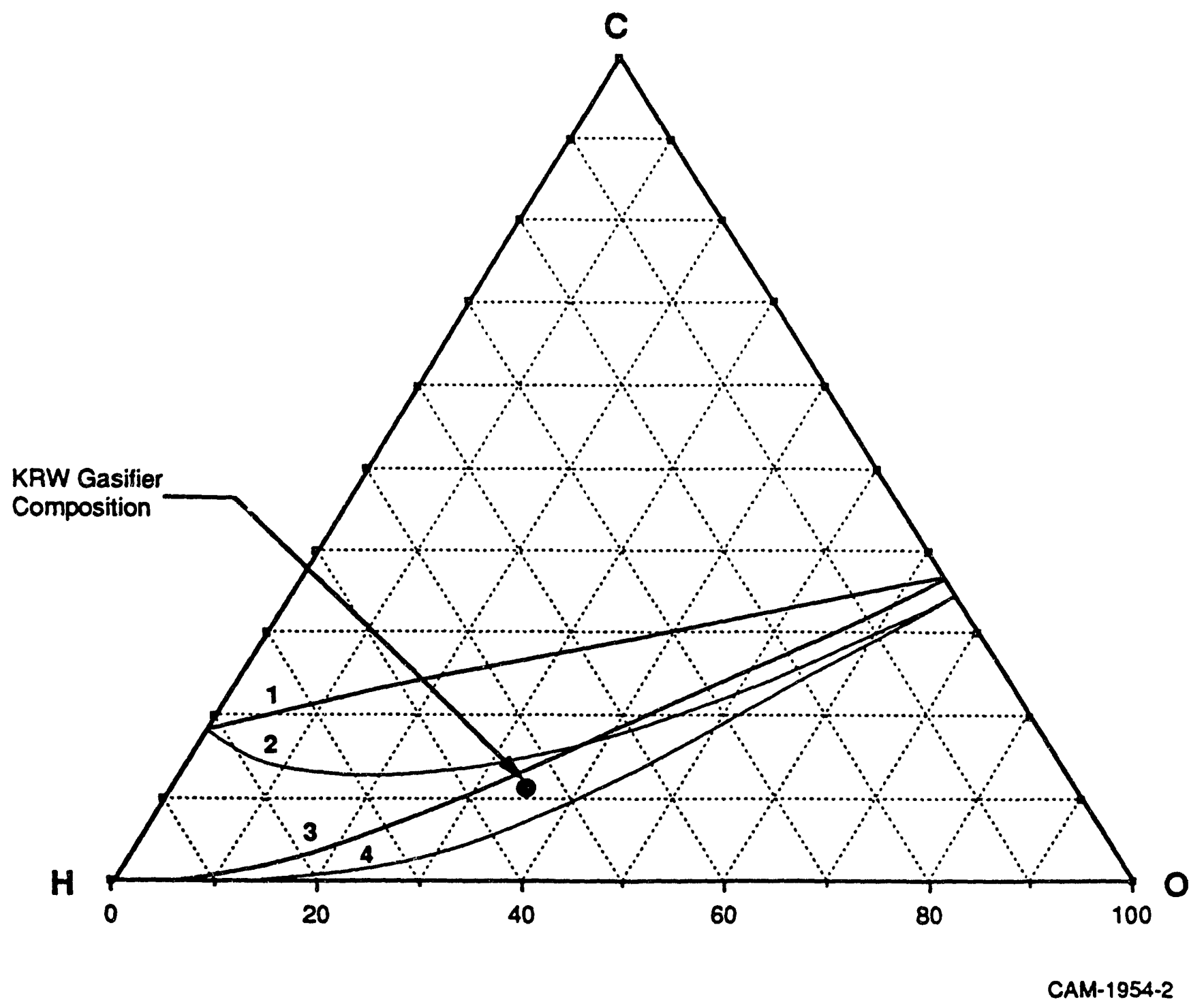

Figure 2. Carbon and carbide boundary lines in a C-H.O system at $550^{\circ} \mathrm{C}$ and $15 \mathrm{~atm}$.

Notes:

Line 1. Carbide boundary line; $\mathrm{CH}_{4}$ included.

Line 2. Carbon boundary line; $\mathrm{CH}_{4}$ included.

Line 3. Carbide boundary line; $\mathrm{CH}_{4}$ not included.

Line 4. Carbon boundary line; $\mathrm{CH}_{4}$ not included. 


\section{EXPERIMENTAL APPROACH}

In this preliminary study, we investigated reactions that can lead to the formation of carbon or carbicies on zinc ferrite sorbents. Fresh and sulfided zinc ferrite sorbents were exposed to carbon-containing gas mixtures $\left(\mathrm{CO} / \mathrm{CO}_{2}, \mathrm{C}_{2} \mathrm{H}_{4}\right.$, or $\mathrm{C}_{6} \mathrm{H}_{6}$ in a helium or nitrogen carrier gas) at $550^{\circ} \mathrm{C}$ and 225 psig. The ratio $\mathrm{CO} / \mathrm{CO}_{2}$ was similar to or lower than that reported in the literature for the KRW fluidized bed gasifier operating in oxygen-blown mode. Thermodynamic calculations indicated that $\mathrm{Fe}_{2} \mathrm{O}_{3}$ is converted to metallic iron in a gas mixture of $\mathrm{CO}-\mathrm{CO}_{2}-\mathrm{N}_{2}$ with a $\mathrm{CO} / \mathrm{CO}_{2}$ ratio greater than 2.3. Hence, we also performed experiments with a $\mathrm{CO} / \mathrm{CO}_{2}$ ratio of 0.72 , where $\mathrm{Fe}_{3} \mathrm{O}_{4}$ is a stable phase.

The KRW gasifier product gas stream is relatively low in tar components. Radian Corporation reported the level of $\mathrm{C}_{2}$-hydrocarbons to be about 30 to $460 \mathrm{ppmv}$ and that of $\mathrm{C}_{6}-\mathrm{C}_{9}$ hydrocarbons to vary from 120 to $470 \mathrm{ppm}$ (Radian Corporation, 1985). For these preliminary experiments, we used 5,000 ppm of $\mathrm{C}_{2} \mathrm{H}_{4}$ and $\mathrm{C}_{6} \mathrm{H}_{6}$ to enhance the rate of carbon deposition.

About $2.5 \mathrm{~g}$ of the zinc ferrite sorbent (labeled as KRW systems, obtained from Research Triangle Institute) was placed inside a 1.3-cm ID stainless steel reactor and heated externally with an electrical resistance heater (Figure 3). The volume of the reactor downstream of the sorbent bed was kept at a minimum to decrease the residence time of the gas stream before it is sampled by the mass spectrometer. The flow rate of the feed gas mixtures was kept at about $85 \mathrm{~cm}^{3} / \mathrm{min}$ (STP), corresponding to a space velocity of $1685 \mathrm{~h}^{-1}$. The sorbent samples were exposed to the gas mixtures for various periods of time ranging from 2 to $16 \mathrm{~h}$.

The temperature programmed reaction (TPR) technique was used to measure the amount and reactivity of carbon deposited on the sorbent. After exposure to the carbonaceous gas mixture, the sample was cooled to ambient temperature and then heated at a constant rate of about $8^{\circ} \mathrm{C} / \mathrm{min}$ in a mixture of $25 \%$ steam- $-75 \%$ He to a maximum temperature of $1000^{\circ} \mathrm{C}$. The space velocity and pressure were kept at $1840 \mathrm{~h}^{-1}$ and 225 psig respectively. The effluent gas stream was analyzed for $\mathrm{CO}, \mathrm{CO}_{2}$, and $\mathrm{CH}_{4}$ by an on-line mass spectrometer. To avoid interference with the analysis of $\mathrm{CO}$, helium was used as the carrier gas in the TPR runs instead of nitrogen ( $\mathrm{CO}$ and $\mathrm{N}_{2}$ have the same atomic mass unit). 


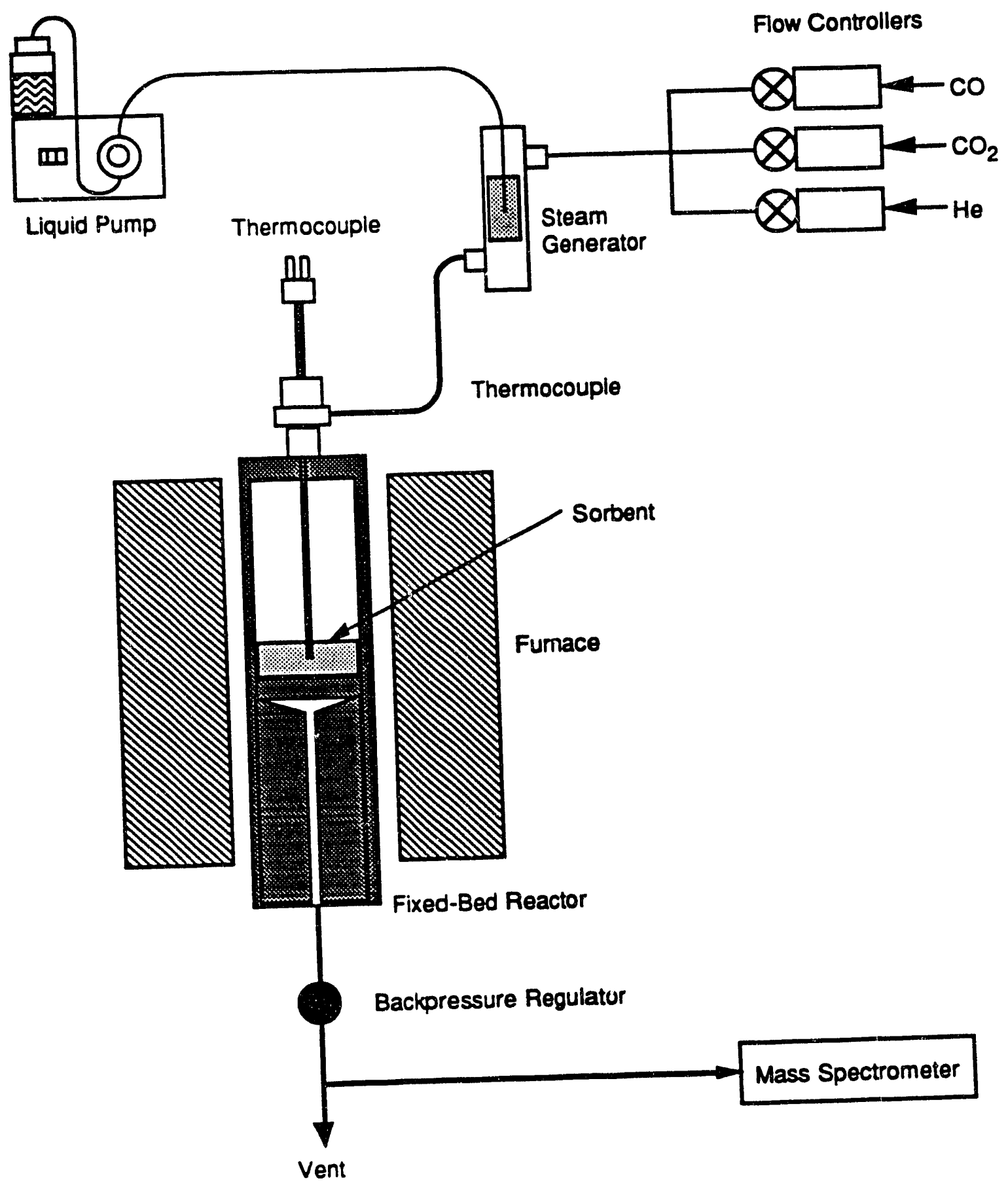

CAM-1954-3

Figure 3. Schematic diagram of the reactor system. 
The TPR results are plotted as the quantity of $\mathrm{CO}$ or $\mathrm{CO}_{2}$ evolved as a function of temperature. Any significant evolution of $\mathrm{CH}_{4}$ was not observed in the TPR experiments with zinc ferrite samples. The formation of $\mathrm{CO}_{2}$ during the TPR run appears to be due to the occurrence of the water gas shift reaction between the steam and $\mathrm{CO}$ produced by the gasification of carbon in the specimen.

$$
\begin{aligned}
\mathrm{C}+\mathrm{H}_{2} \mathrm{O} & =\mathrm{CO}+\mathrm{H}_{2} \\
\mathrm{CO}+\mathrm{H}_{2} \mathrm{O} & =\mathrm{CO}_{2}+\mathrm{H}_{2}
\end{aligned}
$$

At $800 \mathrm{~K}$, the equilibrium constant for the water gas shift reaction is 4.27 and hence $\mathrm{CO}_{2}$ is consistently the major product. 


\section{RESULTS AND DISCUSSION}

Figure 4 illustrates the rate of $\mathrm{CO}$ evolution as a function of temperature when fresh zinc ferrite was heated in a steam-helium gas mixture. In this TPR spectrum, significant $C O$ evolution was observed at about $350^{\circ}$ and $650^{\circ} \mathrm{C}$ which corresponds to the gasification of high and moderate reactivity type carbon deposits, respectively. The peak at $350^{\circ} \mathrm{C}$ may be also due to decomposition of zinc carbonate.

The carbon deposited on zinc ferrite during exposure to a gas stream containing $10.5 \% \mathrm{CO}$, $4.6 \% \mathrm{CO}_{2}$, balance nitrogen for $2 \mathrm{~h}$ at $550^{\circ} \mathrm{C}$ appears to have a low reactivity (Figure 5). The TPR spectrum for $\mathrm{CO}_{2}$ shows a small peak at $650^{\circ} \mathrm{C}$ and a large peak at $920^{\circ} \mathrm{C}$. These results indicate that the carbon deposited by $\mathrm{CO}$ at $550^{\circ} \mathrm{C}$ can be removed by steam at a very slow rate at that temperature. Higher temperatures are necessary to increase the rate of carbon removal by steam.

With a decreased ratio of $\mathrm{CO} / \mathrm{CO}_{2}$ less carbon appeared to be deposited on zinc ferrite. A sorbent sample exposed for $2 \mathrm{~h}$ to a gas stream containing $6.3 \% \mathrm{CO}, 8.8 \% \mathrm{CO}_{2}$, balance nitrogen at $550^{\circ} \mathrm{C}$ exhibited no measurable $\mathrm{CO}$ or $\mathrm{CO}_{2}$ evolution during TPR run. However, increasing the exposure time to $6 \mathrm{~h}$ did result in deposition of carbon, as evidenced by a peak at about $820^{\circ} \mathrm{C}$ during TPR with steam (Figure 6).

Exposure to ethene and benzene $(5,000 \mathrm{ppm}$ each in $\mathrm{He})$ resulted in significant deposition of carbon on zinc ferrite. In the case of ethene, a strong peak is observed at $800^{\circ} \mathrm{C}$ in the TPR spectrum (Figure 7) while two peaks ( at $700^{\circ}$ and $820^{\circ} \mathrm{C}$ ) are observed after benzene exposure (Figure 8).

Sulfided zinc ferrite samples were also exposed to $\mathrm{CO} / \mathrm{CO}_{2}-\mathrm{He}$ and $\mathrm{C}_{2} \mathrm{H} / 4 / \mathrm{He}$ gas mixtures. A fraction of carbon deposited on the sulfided zinc ferrite appeared to be removed by steam at $550^{\circ} \mathrm{C}$, although additional $\mathrm{CO}_{2}$ evolution was observed to occur at $700^{\circ}$ and $1000^{\circ} \mathrm{C}$ (Figure 9). Exposure of the sulfided zinc ferrite to ethene produced a carbon more refractory than that deposited on oxidized zinc ferrite (Figure 10).

The quantity of carbon gasified during the TPR run varied depending on the chemical state of the sorbent (oxidized or sulfided), the nature of the carbon-bearing gas mixture $\left(\mathrm{CO} / \mathrm{CO}_{2}\right.$, $\mathrm{C}_{2} \mathrm{H}_{4}$, or $\mathrm{C}_{6} \mathrm{H}_{6}$ ), and time (Table 2). Carbon deposition appears to be more rapid when the 


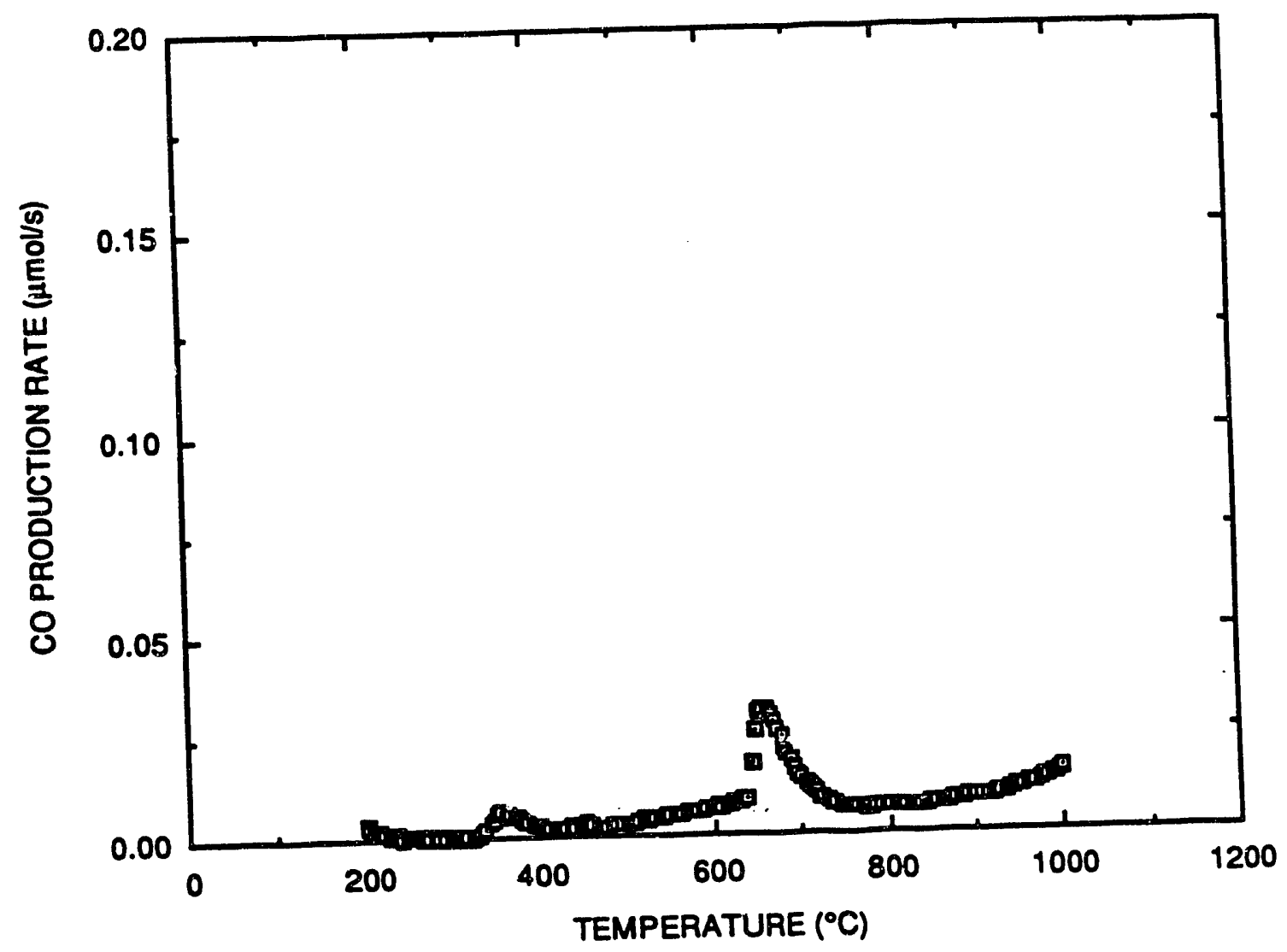

CAM-1054-4

Figure 4. TPR spectrum of carbon present in the zinc ferrite (as received). 


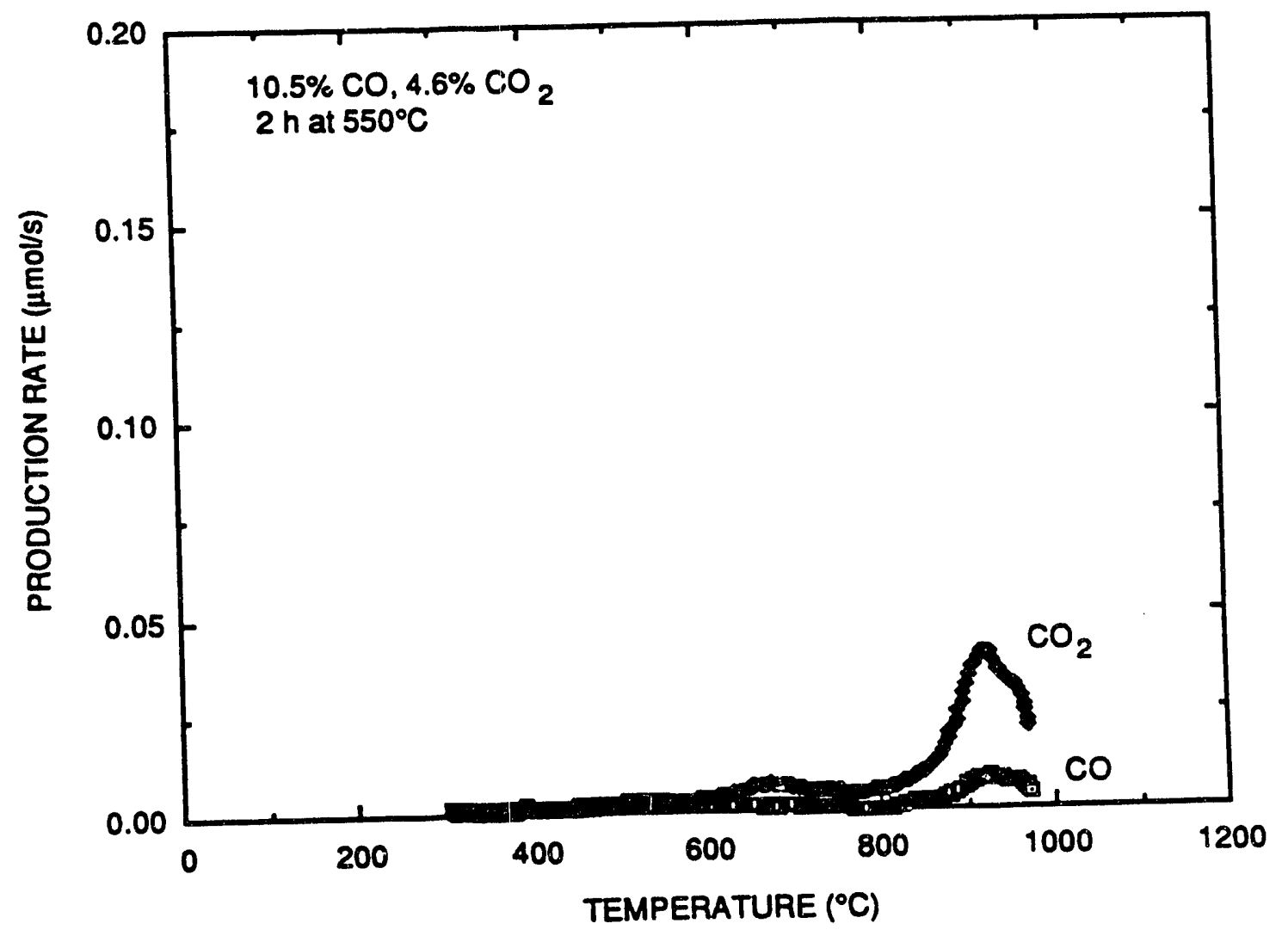

CAM-1954-5

Figure 5. TPR spectrum of carbon deposited by a high $\mathrm{CO} / \mathrm{CO}_{2}$ gas mixture on a zinc ferrite sorbent. 


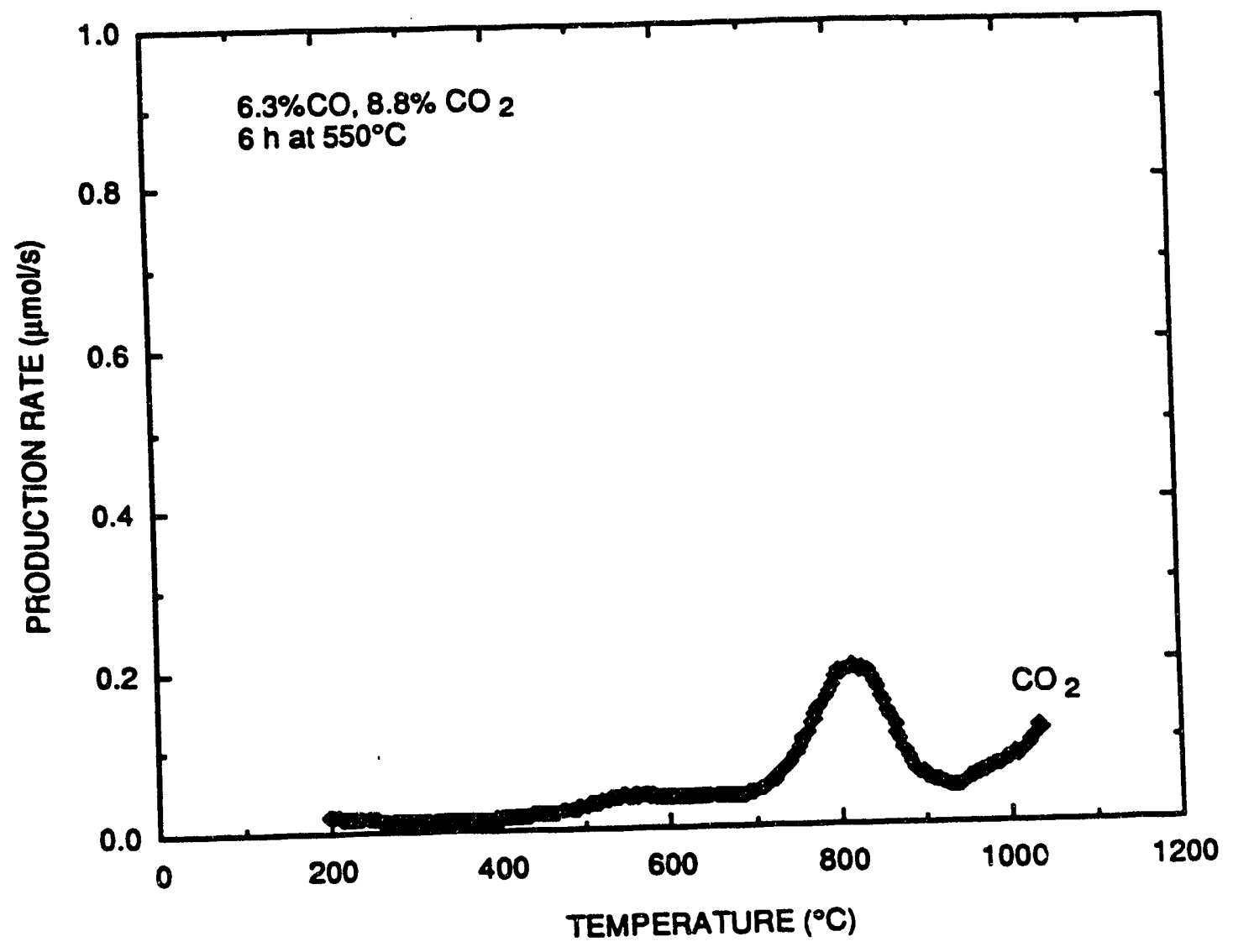

CAMt $1954-6$

Figure 6. TPR spectrum of carbon deposited by a low $\mathrm{CO} / \mathrm{CO}_{2}$ gas mixture on a zinc ferrite sorbent. 


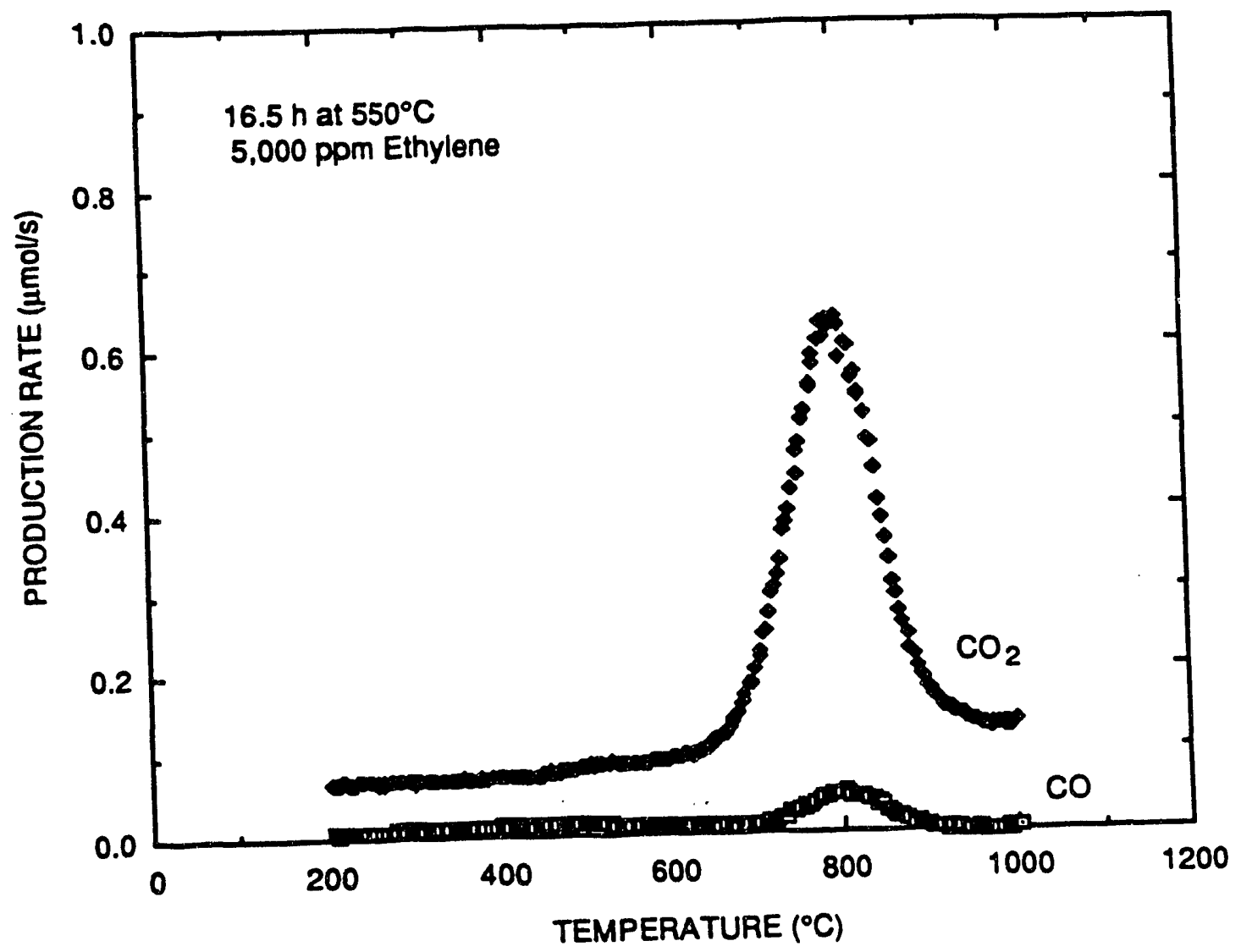

CAM-19547

Figure 7. TPR spectrum of carbon deposited by ethylene on a zinc ferrite sorbent. 


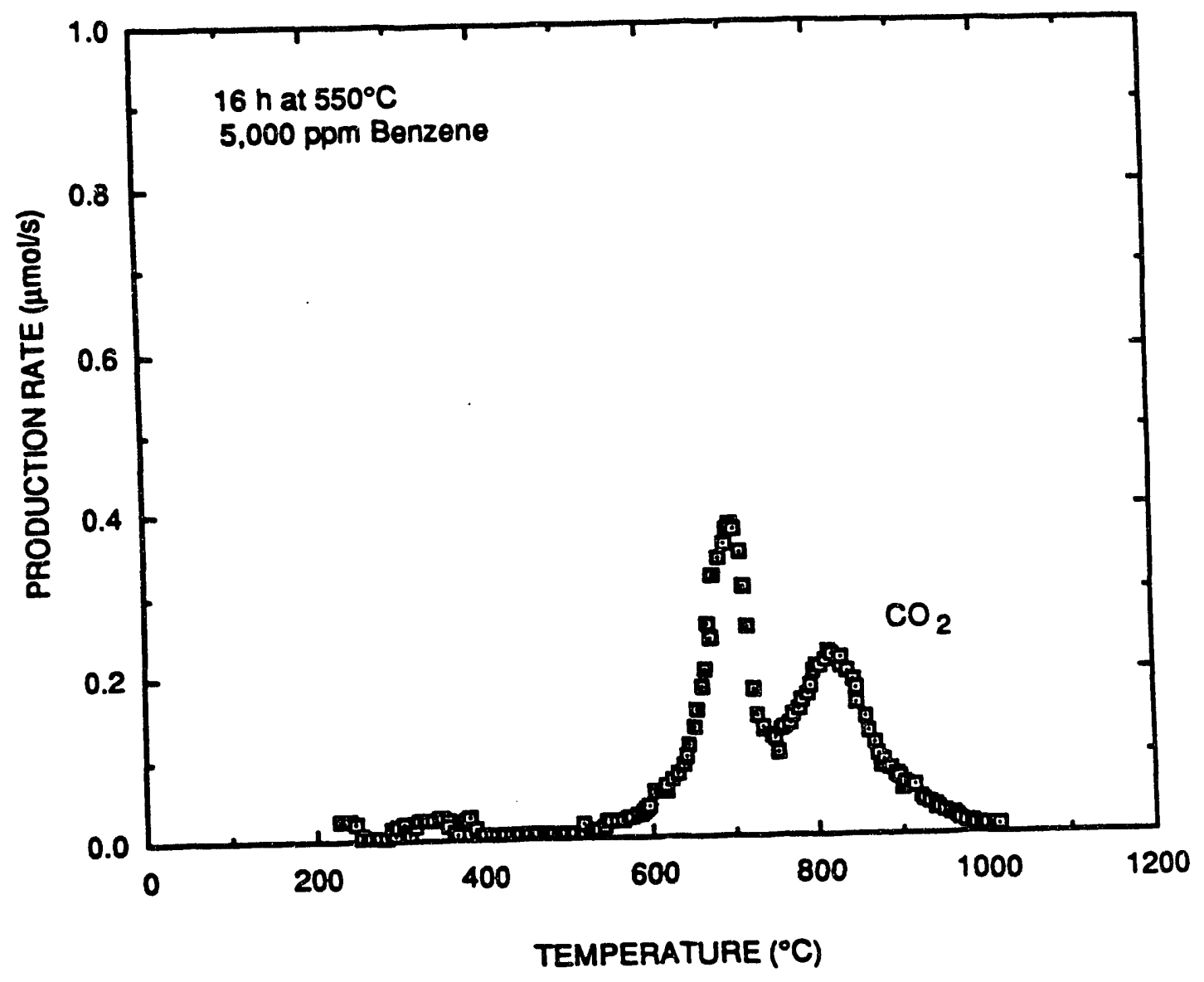

CAM-1854-8

Figure 8. TPR spectrum of carbon deposited by benzene on a zinc ferrite sorbent. 


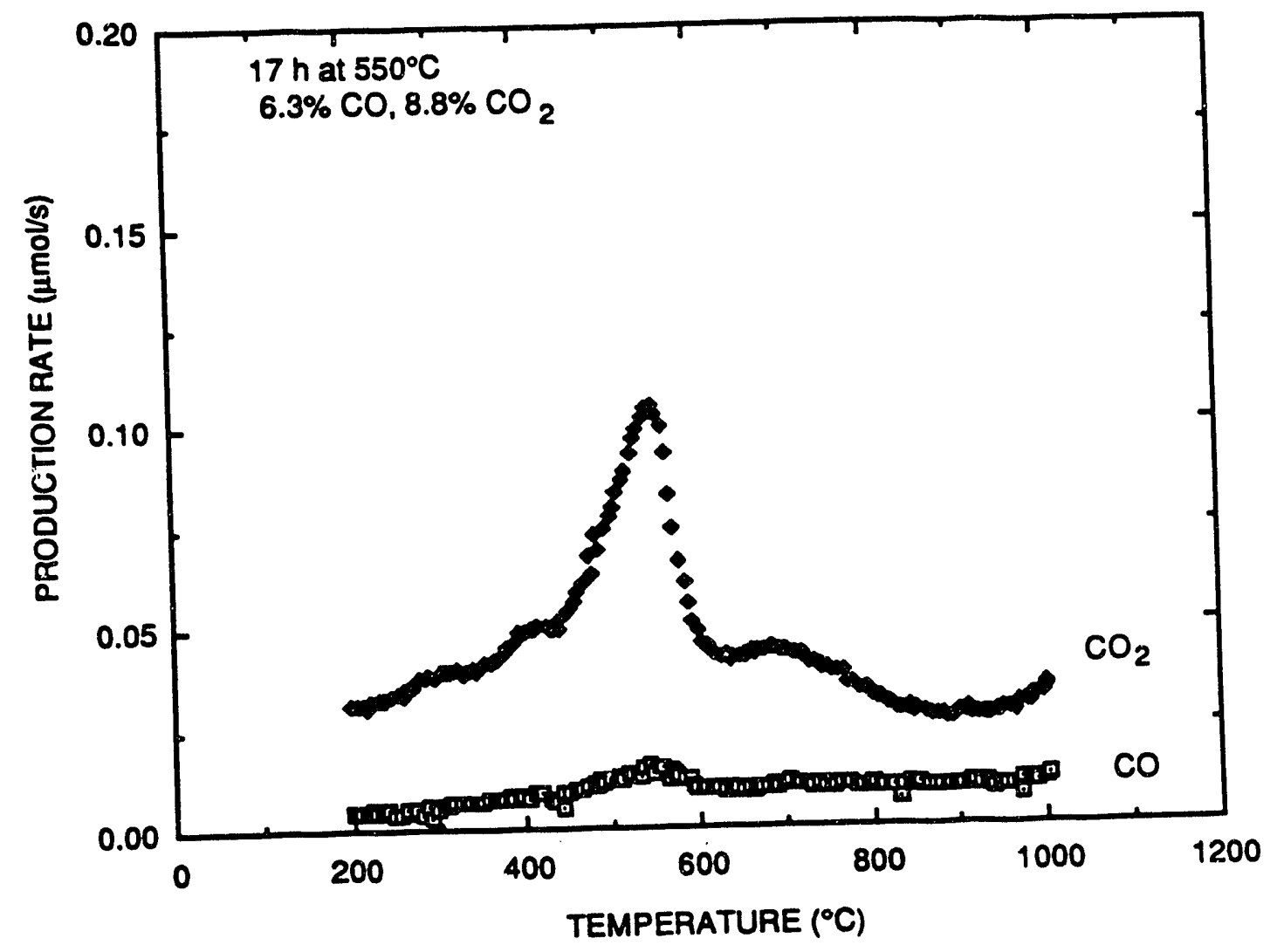

CAM-1954-9

Figure 9. TPR spectrum of carbon deposited by a low $\mathrm{CO} / \mathrm{CO}_{2}$ mixture on a sulfided zinc ferrite sorbent. 


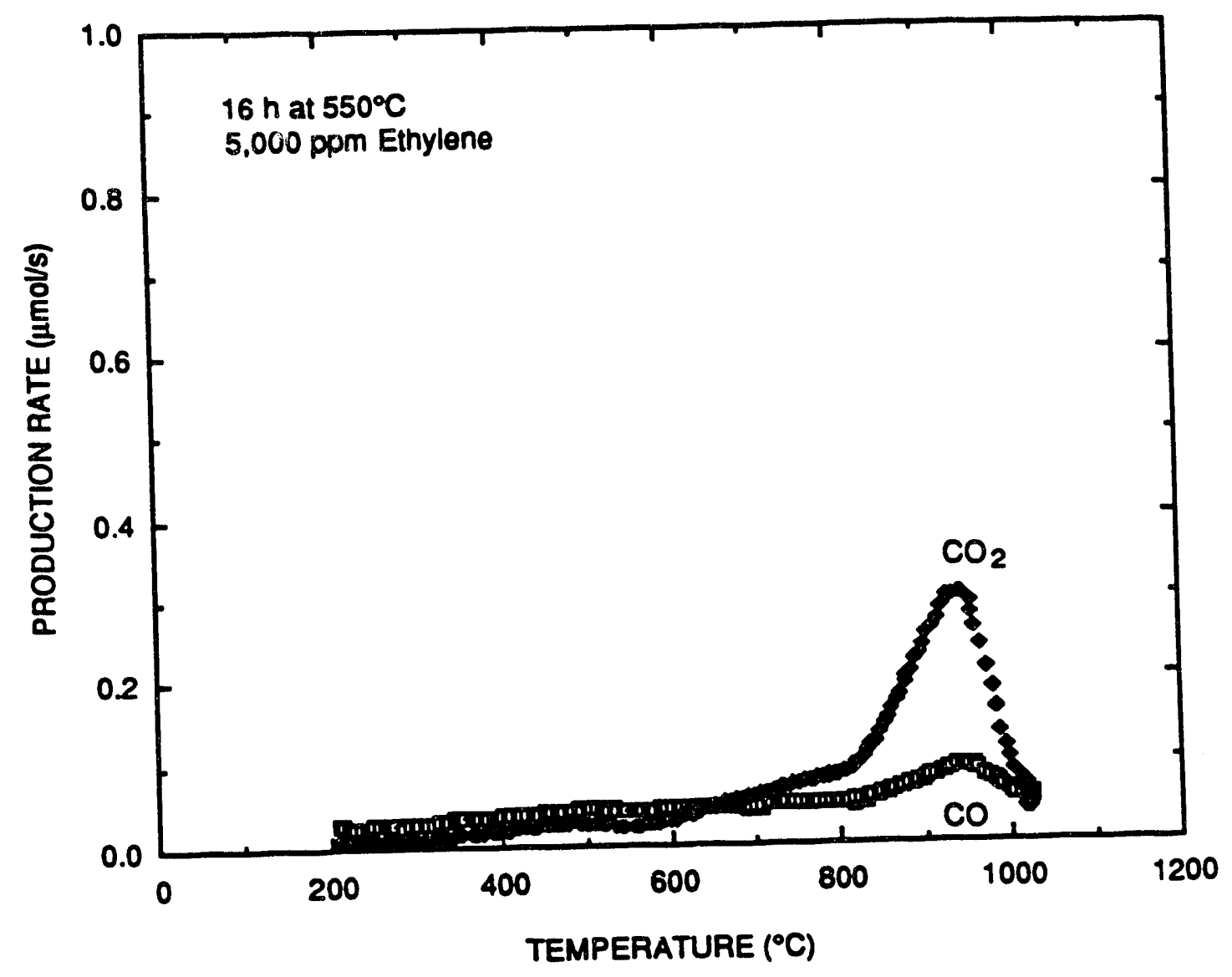

CAM-1054-10

Figure 10. TPR spectrum of carbon deposited by ethylene on a sulfided zinc ferrite sorbent. 
Table 2

QUANTITY OF CARBON DEPOSIT REMOVED BY STEAM GASIFICATION

\begin{tabular}{|c|c|c|}
\hline $\begin{array}{l}\text { Exposure Conditions } \\
\text { (gas Mixture, hours) }\end{array}$ & $\begin{array}{c}\text { Peak Temperature } \\
\left({ }^{\circ} \mathrm{C}\right)\end{array}$ & $\begin{array}{c}\text { Amount of Carbon Gasifled } \\
(w+\%)\end{array}$ \\
\hline \multicolumn{3}{|l|}{ Oxldized Sorbent } \\
\hline Unexposed & 650 & $0.02^{a}$ \\
\hline $\mathrm{CO} \mathrm{CO}_{2}=2.3,2 \mathrm{~h}$ & 920 & 0.03 \\
\hline $\mathrm{CO} / \mathrm{CO}_{2}=0.72,6 \mathrm{~h}$ & 800 & 0.10 \\
\hline $5,000 \mathrm{ppm} \mathrm{C}_{2} \mathrm{H}_{4}, 16 \mathrm{~h}$ & 800 & 0.52 \\
\hline $5,000 \mathrm{ppm} \mathrm{C}_{6} \mathrm{H}_{6}, 16 \mathrm{~h}$ & 700,800 & 0.17 \\
\hline \multicolumn{3}{|l|}{ Sulflded Sorbent } \\
\hline $\mathrm{CO} / \mathrm{CO}_{2}=0.72,17 \mathrm{~h}$ & 520 & $0.01^{b}$ \\
\hline $5,000 \mathrm{ppm} \mathrm{C}_{2} \mathrm{H}_{4}, 16 \mathrm{~h}$ & 920 & $0.11^{c}$ \\
\hline
\end{tabular}

a Analysis by Galbraith Laboratories indicated a total carbon content of 0.02 wt\% of sorbent.

b Analysis by Galbraith Laboratories indicated a total carbon content of 0.11 wt\% of sorbent.

c Analysis by Galbraith Laboratories indicated a total carbon content of 0.07 wt\% of sorbent.

sorbent is in the oxidized state than when it is in the sulfided state. The quantity of carbon deposited was also greater in ethylene than $\mathrm{CO} / \mathrm{CO}_{2}$ gas mixtures.

Selected samples were sent to Galbraith Laboratories, Knoxville, TN, for total carbon analysis. The quantity of carbon calculated from the TPR spectra agreed reasonably with the analyses reported by Galbraith Laboratories except for the experiment in which sulfided zinc ferrite was exposed to the $\mathrm{CO} / \mathrm{CO}_{2}$ mixture. In that sample, Galbraith Laboratories reported about an order-of-magnitude higher carbon content than was calculated from the TPR spectrum. In the carbon analysis by Galbraith Laboratories, the specimen is heated at $1500^{\circ} \mathrm{C}$ in oxygen and the total amount of $\mathrm{CO}_{2}$ evolved is measured. This procedure determines the total quantity of carbon present in the specimen irrespective of the carbon reactivity. The excess carbon found during this analysis represents a very unreactive carbon that may be too slow to gasify with steam below $1000^{\circ} \mathrm{C}$. In fact, the TPR spectrum (Figure 9) indicates a rise in $\mathrm{CO}_{2}$ evolution at about $1000^{\circ} \mathrm{C}$.

The data from the TPR experiments can be analyzed to estimate whether a carbon deposit will accumulate on the sorbent. The average rate of carbon deposition was calculated during $\mathrm{CO}$, 
$\mathrm{C}_{2} \mathrm{H}_{4}$, or $\mathrm{C}_{6} \mathrm{H}_{6}$ exposure by assuming that the rate is constant with time. The rate of carbon removal by steam at $550^{\circ} \mathrm{C}$ and 15 atm was calculated from Arrhenius plots of the TPR spectra. In these plots, an example of which is shown in Figure 11, the $\log$ (Rate of $\mathrm{CO}_{2}$ evolution/amount of carbon remaining) is plotted against $1 / \mathrm{T}$. The rate of carbon removal at $550^{\circ} \mathrm{C}$ was calculated by extrapolating the linear portion of the curve and multiplying by the amount of carbon remaining at that temperature. The carbon deposition and removal rates are summarized in Table 3.

Table 3

RATE OF CARBON REMOVAL BY STEAM AT $550^{\circ} \mathrm{C}$ AND 15 ATM

\begin{tabular}{|c|c|c|}
\hline Exposure Conditions & $\begin{array}{c}\text { Average Rate of Carbon } \\
\text { Depositlon } \\
\left(\mathrm{g} \cdot \mathrm{h} \cdot 1 \cdot \mathrm{g}^{-1} \text { of sorbent) }\right.\end{array}$ & $\begin{array}{c}\text { Rate of Carbon Removal by } \\
\text { Steam at } 550^{\circ} \mathrm{C} \\
\left(\mathrm{g} \cdot \mathrm{h}^{-1} \cdot \mathrm{g}^{-1} \text { of sorbent) }\right.\end{array}$ \\
\hline \multicolumn{3}{|l|}{ Oxidized Sorbent } \\
\hline Unexposed & N.A. & $5.2 \times 10^{-4}$ \\
\hline $\mathrm{CO} / \mathrm{CO}_{2}=2.3,2 \mathrm{~h}$ & $1.5 \times 10^{-4}$ & $8 \times 10^{-10}$ \\
\hline $\mathrm{CO} / \mathrm{CO}_{2}=0.72,6 \mathrm{~h}$ & $1.7 \times 10^{-4}$ & $3.7 \times 10^{-6}$ \\
\hline $5,000 \mathrm{ppm} \mathrm{C} \mathrm{H}_{4}, 16 \mathrm{~h}$ & $3.2 \times 10^{-4}$ & $9.9 \times 10^{-6}$ \\
\hline $5,000 \mathrm{ppm} \mathrm{C} 6 \mathrm{H}_{6}, 16 \mathrm{~h}$ & $1.0 \times 10^{-4}$ & $\begin{array}{l}5.6 \times 10^{-6} \text { to } \\
3.3 \times 10^{-5}\end{array}$ \\
\hline \multicolumn{3}{|l|}{ Sulfided Sorbent } \\
\hline $\mathrm{CO} / \mathrm{CO}_{2}=0.72,17 \mathrm{~h}$ & $6.5 \times 10^{-5}$ & $4.3 \times 10^{-3}$ \\
\hline $5,000 \mathrm{ppm} \mathrm{C}_{2} \mathrm{H}_{4}, 16 \mathrm{~h}$ & $6.9 \times 10^{.5}$ & $5.6 \times 10^{-9}$ \\
\hline
\end{tabular}

In these experiments, the carbon was deposited using a simulated gas stream that does not contain any steam. In an actual coal gas stream, both carbon deposition and its removal by steam are occurring simultaneously and hence, the actual amount of carbon deposited could be less than found in these experiments. However, the present experiments suggest that carbon removal rates are very slow and carbon that is deposited under nonequilibrium or gasifier upset conditions may not be removed rapidly leading to an accumulation of carbon deposits. Accumulation of carbon deposits may decrease the rate and capacity of $\mathrm{H}_{2} \mathrm{~S}$ uptake by the sorbent. As indicated previously, formation of iron carbides have a deleterious effect on the attrition resistance of the zinc 
ferrite sorbents. Presence of carbon deposits and carbides in the sulfided sorbents may lead to an excessive increase in the temperature during the oxidative regeneration.

Carbon monoxide appears to be the primary source of carbon deposits on the zinc ferrite sorbent. Although the rate of carbon deposition is not very high $\left(\sim 1.5 \times 10^{-4} \mathrm{~g}\right.$ of C $\cdot \mathrm{h}^{-1} \cdot \mathrm{g}^{-1}$ sorbent) the removal rate by steam is also very low $\left(8 \times 10^{-10}\right.$ to $4 \times 10^{-6} \mathrm{~g}$ of $\mathrm{C} \cdot \mathrm{h}^{-1} \cdot \mathrm{g}^{-1}$ of sorbent). Hence, in this environment carbon is likely to accumulate on the zinc ferrite sorbent. 


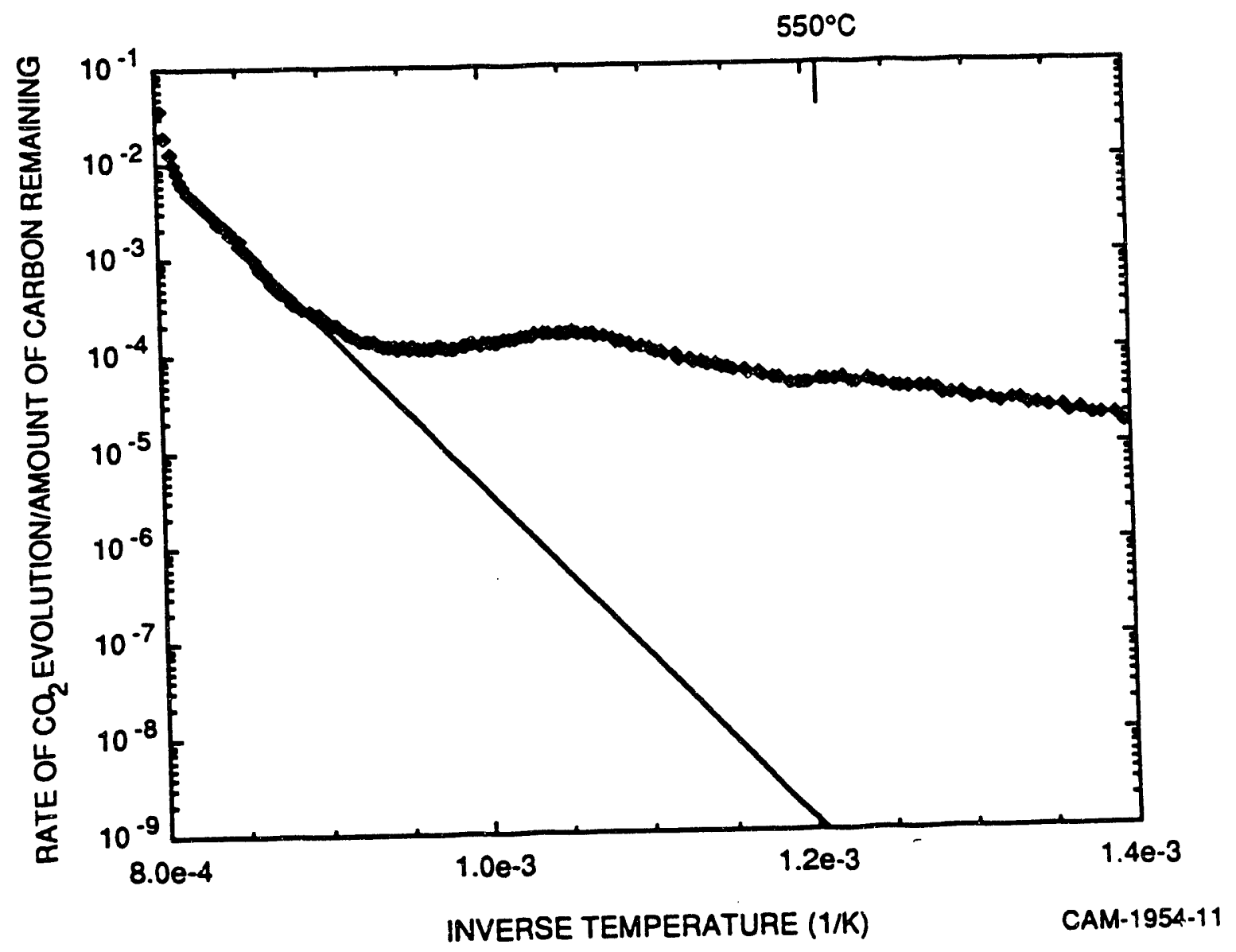

Figure 11. Plot oi log(Rate of carbon removal/amount or carbon remaining) vs inverse temperature 


\section{CONCLUSIONS AND RECOMMENDATIONS}

From the analysis of the experimental data and theoretical calculations, the following conclusions were reached:

- Thermodynamic calculations indicate that carbon deposition and carbide formation occur under a broader range of conditions if reactions such as methane formation are slow.

- Carbon monoxide is the primary source of carbon deposits on zinc ferrite sorbents. Carbon deposition rate exceeds the rate of removal by steam, and hence carbon is likely to accumulate on the sorbent.

- Hydrocarbons such as $\mathrm{C}_{2} \mathrm{H}_{4}$ and $\mathrm{C}_{6} \mathrm{H}_{6}$ can also deposit carbon on the sorbent, but their very low concentrations in advanced fluidized- and entrained-bed gasifier gas streams may preclude them from being a major source of carbon deposits.

For future work in this area, the following studies are recommended:

- Detailed experimental and theoretical research should be undertaken to determine the thermodynamics and kinetics of cumulative carbon deposition and carbide formation. The investigation should include conditions representative of fixed bed, fluidized bed, and entrained bed gasifier systems. Carbon deposition and carbide formation rnay be severe in entrained bed gasifier system.

- Similar studies should be extended to other hot coal gas desulfurization sorbents. Carbon deposition may occur on sorbents that do not contain iron oxides (e.g. zinc titanate). Sorbents containing iron oxide (e.g. copper-iron oxides) may be prone to carbide formation in addition to carbon deposition.

- The change in the attrition resistance of hot coal gas desulfurization sorbents on which carbon deposition and carbide formation occur needs to determined. The useful lifetime of the sorbents may be reduced because of potential auverse effects of these reactions on the mechanical strength of the sorbents. 


\section{REFERENCES}

G. B. Haldipur, D. K. Schmidt, and K. J. Smith, "A 50-Month Gasifier Mechanistic Study and Downstream Unit Process Development Program for the Pressurized Ash-Agglomerating Fluidized-Bed Gasification System," Final Report by KRW Energy Systems, Inc., to U.S. Department of Energy, Report No. DOE/MC/21063-2740 (1.989).

R. H. Lamoreaux, R. D. Brittain, J. Zeiger, and S. C. Leach, "Determination of Solid Phase Boundaries in Coal Gas Desulfurization by Zinc Ferrite," Final Report by SRI international to U.S. Department of Energy under Contract No. DE-AC21-84MC21096 (1986).

Radian Corporation, "Environmental, Health and Safety Data Base for the KRW Coal Gasification Process Development Unit," Report to Gas Research Institute, Report No. PB86-102779 (1985).

E. T. Turkdogan, Physical Chemistry of High Temperature Technology, Academic Press, New York, 412 (1980).

W. C. Reynolds, "The Element Potential Method for Chemical Equilibrium Analysis; STANJAN Computer program, Version 3," Department of Mechanical Engineering, Stanford University (1986). 

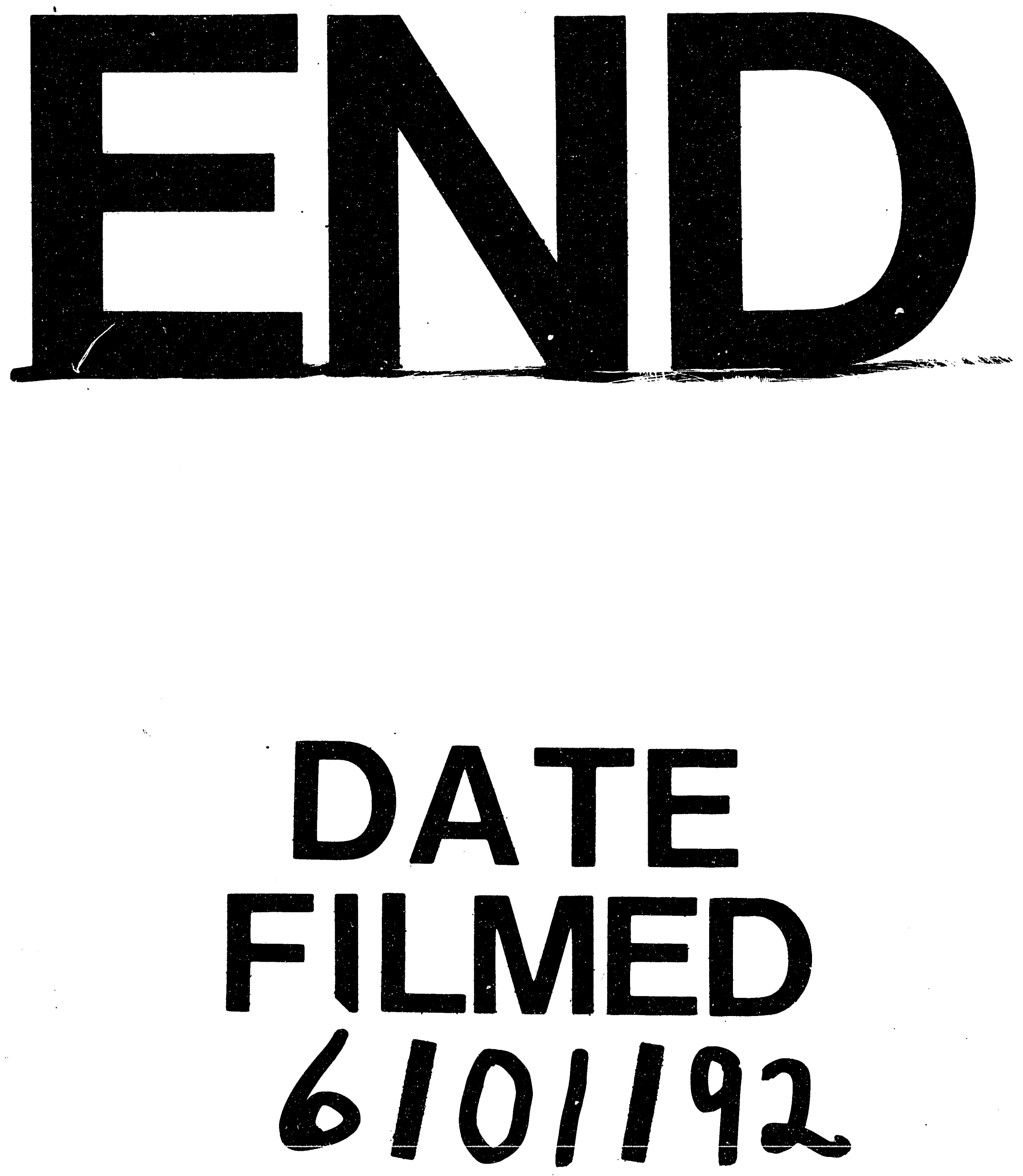


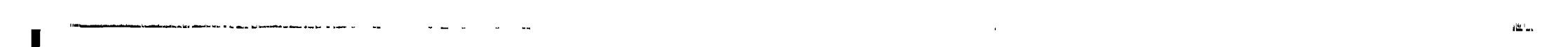

